\title{
THE STUDY OF PROPERTIES OF POLYMERIC STABILIZED EMULSIONS BASED ON ARISTOFLEX
}

\author{
T.Kovaliova, N.Polovko \\ National University of Pharmacy
}

Key words: emulsion; emulsifier; polymeric viscosity controllers; rheological properties; structural viscosity

The present work contains the study of stabilizing properties of Aristoflex AVC polymeric viscosity modifier and stabilizer of the oil/water type emulsion systems. The technological, physicochemical and rheological studies of emulsions on basis of the Aristoflex polymeric viscosity controller have been conducted. It has been proven that they are structured disperse systems with certain thixotropic properties. The results of the research indicate the prospects of using Aristoflex as a monostabilizer in the concentration of $1-2.5 \%$ with the oil phase content of 5-30\%, respectively. It has been found that introduction of Aristoflex to the water or oil phase does not affect their organoleptic, physicochemical and rheological properties.

An important issue in the industrial production of therapeutic and cosmetic creams is their stability during storage; therefore, the rational selection of stabilizing components is of current importance at the stage of development and planning of the cream production. The traditional practice of obtaining emulsion systems is based on the use of surfactants, which role consists in decreasing the interphase tension, as well as in combining surfactants with gelling agents that raise the stability of emulsions thanks to the ability to form viscous high-tensile colloidal structures. However, there are data on the irritating effect of creams on the basis of conventional emulsifiers on the skin, and it makes the search and study of new stabilizing additives topical $[2,4,5]$.

In recent years a number of publications described the experience of application of stabilizers combining electrostatic and steric mechanisms of emulsion stabilization [6]. Such substances have a polymeric nature and can stabilize emulsion systems as monoemulsifiers. Having the properties of anionic surfactants such polymers prevent the loss of the aggregate resistance of emulsions due to electrostatic repulsion of disperse phase particles, and their branched spatial structure provides the steric stabilization of emulsions with formation of a gelatinous structure in the zone of overlapping adsorption and solvation layers [3, 6-8].

The aim of this work was to study organoleptic, structural and mechanical properties of emulsion bases stabilized by a copolymer of acrylamido-methyl-propane-sulfonic acid and vinyl-pyrrolidone (Aristoflex AVC, ClariantSurfactants, Germany), hereinafter referred to as Aristoflex. Aristoflex belongs to the group of modern viscosity modifiers and stabilizers of emulsion systems of the oil/water type where it is used both in combination with conventional emulsifiers and as a monostabilizer makingdermatologically soft cream-gel systems known as surfactant-free without the irritating effect on the skin [9-11].

\section{Materials and Methods}

The subjects of the study were two batches of emulsion bases of the oil/water type prepared by the cold emulsification method with variations of the content of oil with the constant quantity of the emulsifier in the first batch and the content of the emulsifier with the constant quantity of the oil phase in the second batch.

The colloidal and thermal stability were determined in accordance with the methods of the State Standard (GOST) for "cosmetic creams". The type of emulsion was determined by the dilution method. The $\mathrm{pH}$ indicators of the experimental samples were determined by potentiometry in $10 \%$ water extraction of the cream by a MI pH meter (Russia) with $\mathrm{pH} 150$ according to the II ed. of the State Pharmacopoeia of Ukraine (SPhU) [1]. The rheological studies were conducted with a BROOKFIELD HB DV-II PRO viscosimeter (USA) within the range of the shear rate from $18.6 \mathrm{sec}^{-1}$ to $93 \mathrm{sec}^{-1}$ (SC4-21 spindle for $8.3 \mathrm{ml}$ chamber) at the temperature of $20^{\circ} \mathrm{C}$. Based on the measurement results the rheograms of the shear stress $(\tau)$ versus the shear rate gradient (Dr), as well as the diagram of the structural viscosity $(\eta)$ - shear rate (Dr) relationship were built. The presence of thixotropic properties of the samples was determined by appearance of the fluidity curve.

The microscopic analysis was conducted by a "Konus-Akademy" laboratory microscope with a ScopeTek DCM510 ocular camera. The ScopePhoto ${ }^{\mathrm{TM}}$ software was used for image visualization.

\section{Results and Discussion}

Both technologies proposed by the manufacturer were used while preparing the experimental samples: the preliminary introduction of Aristoflex to the oil phase before its mixing with the water phase and introduction to the water phase. The samples with the same organoleptic, technological and tactile indices were obtained, and subjected to the thermal and colloidal stability tests; as a result, stable samples were selected for further studies (Table). 
Experimental samples with Aristoflex AVC and their indices

\begin{tabular}{|c|c|c|c|c|}
\hline $\begin{array}{l}\text { Sample } \\
\text { No. }\end{array}$ & Aristoflex, \% & Oil phase, $\%$ & Sensory characteristics of the sample & $\begin{array}{c}\text { Structural viscosity } \\
\mathrm{mPa} \cdot \mathrm{s}^{-1}\end{array}$ \\
\hline \multicolumn{5}{|c|}{ Batch 1} \\
\hline 1 & 2.0 & 5.0 & \multirow{2}{*}{$\begin{array}{l}\text { A matte cream of a white colour and medium consistency } \\
\text { is absorbed without leaving a trace and stickiness }\end{array}$} & 10200 \\
\hline 2 & 2.0 & 10.0 & & 12000 \\
\hline 3 & 2.0 & 15.0 & \multirow{2}{*}{$\begin{array}{l}\text { A glossy cream of a white colour and thick consistency is } \\
\text { absorbed without leaving a trace and stickiness }\end{array}$} & 12500 \\
\hline 4 & 2.0 & 20.0 & & 13300 \\
\hline 5 & 2.0 & 25.0 & \multirow{2}{*}{$\begin{array}{l}\text { A glossy cream of a white colour and thick consistency } \\
\text { gives a greasy feeling to the skin when applied, is } \\
\text { absorbed without leaving a trace and stickiness }\end{array}$} & 15600 \\
\hline 6 & 2.0 & 30.0 & & 17400 \\
\hline \multicolumn{5}{|c|}{ Batch 2} \\
\hline 8 & 1.0 & 20.0 & $\begin{array}{l}\text { A translucent cream-gel is quickly absorbed without } \\
\text { leaving a trace and stickiness }\end{array}$ & 4900 \\
\hline 10 & 1.5 & 20.0 & $\begin{array}{l}\text { A matte cream of a white colour and thick consistency } \\
\text { is absorbed without leaving a trace and stickiness }\end{array}$ & 9500 \\
\hline 4 & 2.0 & 20.0 & \multirow{2}{*}{$\begin{array}{l}\text { A glossy cream of a white colour and thick consistency } \\
\text { is absorbed without leaving a trace and stickiness }\end{array}$} & 13300 \\
\hline 11 & 2.5 & 20.0 & & 15500 \\
\hline
\end{tabular}

It has been found that being within the range of concentrations of $1-2.5 \%$ Aristoflex is capable of stabilizing emulsion systems without introduction of an additional emulsifier. The attempts to obtain stable emulsions with $0.5 \%$ concentration of Aristoflex and $5 \%$ oil concentration resulted in their destruction within the first day after preparation. The samples with the Aristoflex concentration of more than $2.5 \%$ were too viscous indicating their low consumer properties.

It is known that the structural viscosity of disperse systems formed with the help of polymeric stabilizers determines their thickening properties. That is why the next step of our investigation was to study the relationship between the structural viscosity of the samples obtained and the Aristoflex concentration (Fig. 1).

As it is shown by the results of the studies, viscosity of the emulsion system under study considerably increased with the increase of the Aristoflex concentration from $1.0 \%$ to $2.5 \%$. Therefore, the excipient used as a monostabilizer of the oil/water type emulsions is effective.

The rheograms of the emulsion samples were also built, their hysteresis loop area indicated the thixotropic properties with a different degree of manifestation (Fig. 2, 3).

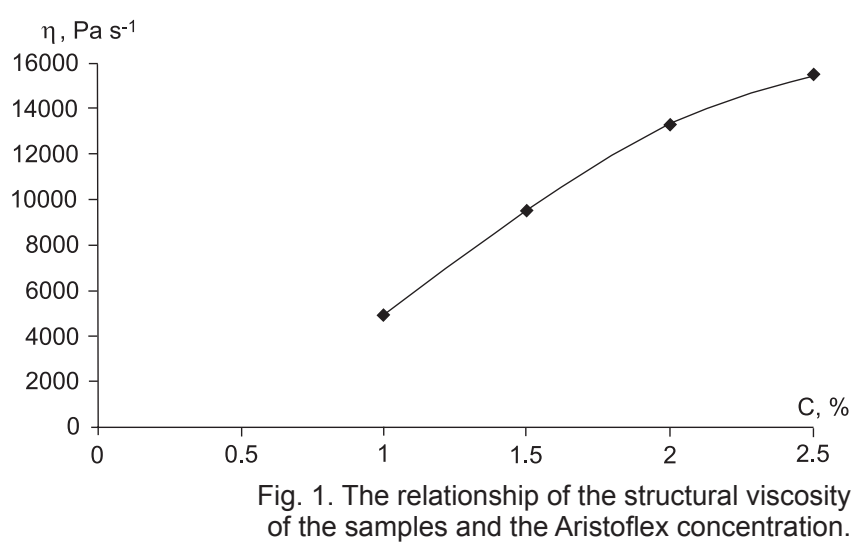

The rheograms built show the uniformity of the flow of the samples under research, as well as their compliance with the non-Newtonian type with plastic properties.

The study of the relationship of the structural viscosity and the shear rate gradient of the emulsion samples with Aristoflex in the concentration of 1-2.5\% showed a gradual decrease of the structural viscosity with increase in the shear rate gradient (Fig. 4, 5).

The most intensive decrease of the structural viscosity is observed within the shear rate range from $20 \mathrm{~s}^{-1}$ to $40 \mathrm{~s}^{-1}$, then viscosity decrease occurs insignificantly and almost does not change at the deformation rate of $55 \mathrm{~s}^{-1}$. It indicates the structure destruction.

The dispersion degree of particles is one of the criteria determining the consistency and stability of emulsions. It is considered that an optimal particle size of the

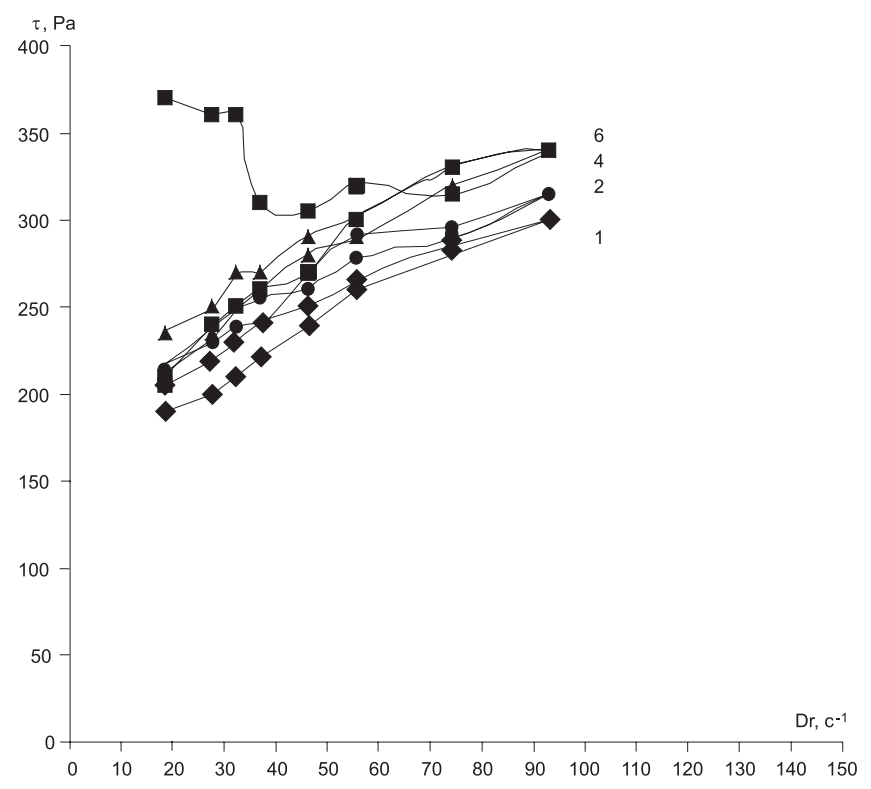

Fig. 2. The rheograms of emulsion samples No. 1, 2, 4, 6 with Aristoflex in $2 \%$ concentration with $5-30 \%$ concentration of the oil phase. 


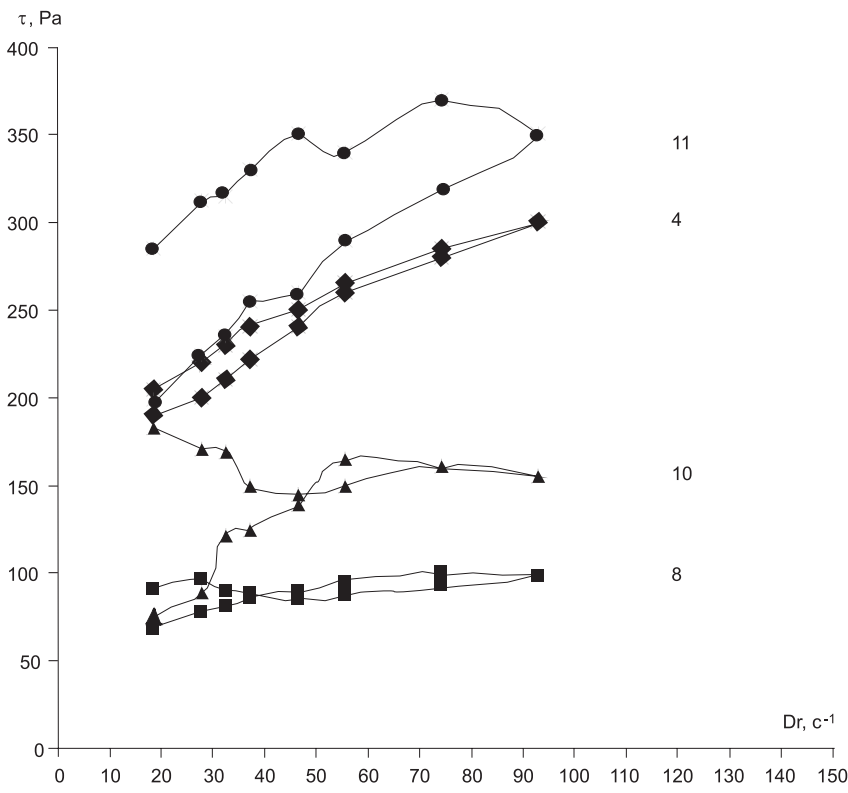

Fig. 3. The rheograms of emulsion samples No. 1, 2, 4, 6 with Aristoflex in $1-2.5 \%$ concentration with $20 \%$ concentration of the oil phase.

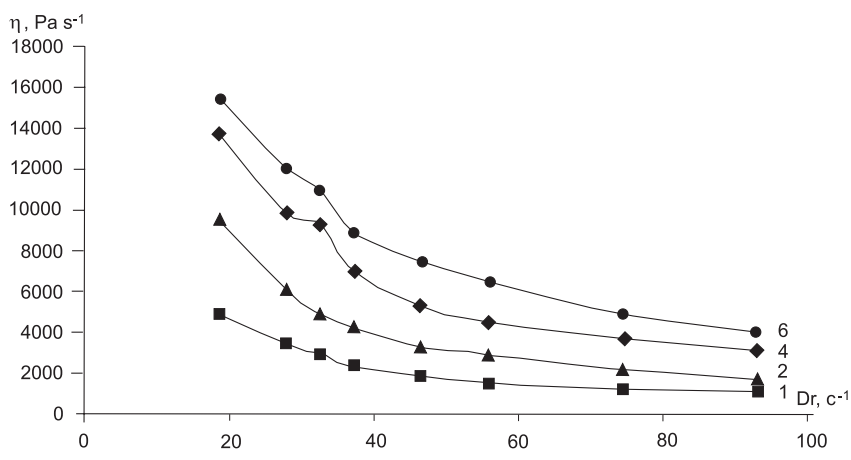

Fig. 4. The relationship of the structural viscosity and the shear rate in the experimental samples with Aristoflex in $2 \%$ concentration with $10-30 \%$ concentration of the oil phase.

emulsion cream is 1-2 $\mu \mathrm{m}$. Thus, our next step was the microscopic examination of the experimental emulsion samples; it allowed to determine finally an optimal emulsifier concentration in stable samples (Fig. 6a, b, c, d).

Dispersion analysis of the emulsions with different Aristoflex concentrations has shown that samples No. 1, 2, 6 have a heterogeneous drop size from 1 to $2 \mu \mathrm{m}$; in sample No. 1 there is enlargement of the emulsion particles indicating coalescence. Monodispersity and high density of drops in sample No. 4 are the evidence of a concentrated nature of the dispersed phase and allow to refer it to the ultramicroheterogeneous system.

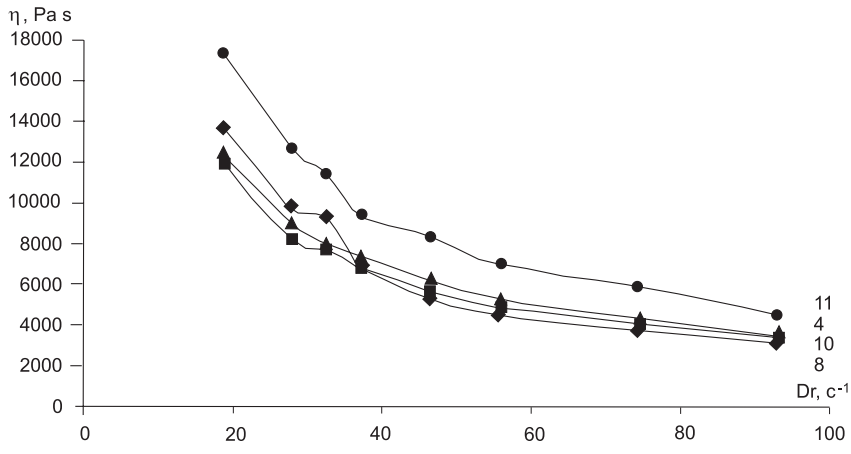

Fig. 5. The relationship of the structural viscosity and the shear rate in the experimental samples with Aristoflex in 1-2.5\% concentration with $20 \%$ concentration of the oil phase.

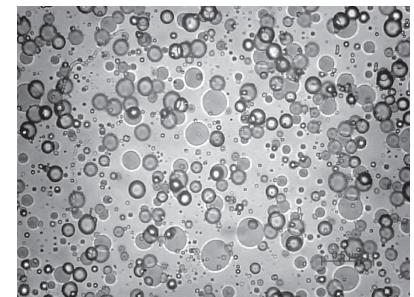

a

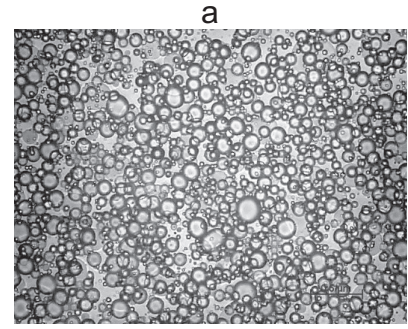

C

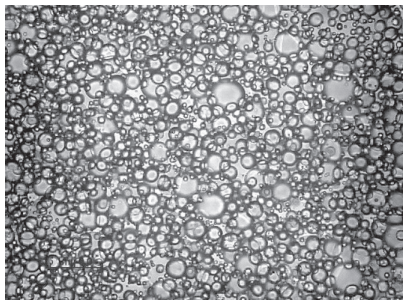

b

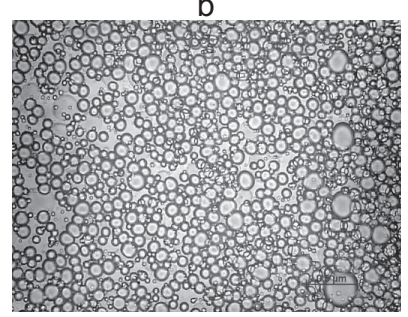

d
Fig. 6. Dispersity of the particles of the oil phase of the experimental samples where: a - sample 1 b-sample 2 , c - sample 6 , d - sample 4 .

\section{CONCLUSIONS}

The technological, physicochemical and rheological studies of emulsions on basis of the Aristoflex polymeric viscosity controller have been conducted. It has been proven that they are structured disperse systems with certain thixotropic properties.

The results of the research indicate the prospects of using Aristoflex as a monostabilizer in the concentration of $1-2.5 \%$ with the oil phase content of $5-30 \%$, respectively, the optimal concentration is $2 \%$.

It has been found that introduction of Aristoflex to the water or oil phase does not affect their organoleptic, physicochemical and rheological properties.

\section{REFERENCES}

1. Державна фармакопея Украӥни / Державне підприємство «Український науковий фармакопейний ичентр якості лікарських засобів». - 2-е вид. - Х.: ДП «Украӥнський науковий фармакопейний ичентр якості лікарських засобів», 2014. - T. 1. - С. 51.

2. Дмитрієвський Д.І., Рибачук В.Д., Хоменко В.М. та ін. Допоміжні речовини в технології ліків: вплив на технологічні, споживчі, економічні характеристики і терапевтичну ефективність: Навч. посіб. для студ. вищ.. фармац. навч. закл. / За ред. І.М.Периева. - Х.: Золоті сторінки, 2010. - 600 с.

3. Ковальова Т.М. // Вісник фармаціï. - 2015. - №1 (81). - C. 38-41.

4. Кути Г. Косметические кремы и эмульсии. Состав, методы получения и испьтаний. - М.: Косметика и медицина, 2004. - 272 c. 
5. Структура и текстура пищевых продуктов. Продукты эмульсионной природы / Под ред. М.Б.МакКенна. С.Пб.: Профессия, 2008. - 471 c.

6. Jingyu Shi. Steric Stabilization. - Columbus: The Ohio State University, 2002. - 43 p.

7. Loffer M., Miller D., Henning T. [Електронний pecypc] // Household \&Personal Products Industry, 2002. Режим доступy: https://www. highbeam.com

8. Manor O., Chau T.T., Stevens G.W. et al. // Langmuir. - 2012. - Vol. 28, №10. - P. 4599-4604.

9. Pat. CN102573785 (A), A 61 K8/06, A 61 K8/35. Oil-in-water emulsion with improved sensory properties / Chantal Amalric, Juanshu Shen, J.Guilbot, Rolland H. Gorce A., S.Kerverdo; SEPPIC. - № 20100722; Publ. 2012-07-11.

10. Pat. WO2005025522 A2. Skin care composition / Yasuko Nmn Suginaka. - № CA2536204A1. - Appl.: 31.08.2004. Publ.: 24.03.2005.

11. Wang L., Fang J. // Central Eur. J. of Energetic Materials. - 2013. - Vol. 10, №1. - P. 87-102.

ВИВЧЕННЯ ВЛАСТИВОСТЕЙ ПОЛІМЕР-СТАБІЛІЗОВАНИХ ЕМУЛЬСІЙ НА ОСНОВІ

ARISTOFLEX

Т.М.Ковальова, Н.П.Половко

Ключові слова: емульсія; емульгатор; полімерні регулятори в'язкості; реологічні

властивості; структурна в'язкість

Робота містить дослідження стабілізуючих властивостей полімерного модифрікатора в'язкості і стабілізатора емульсійних систем типу олія/вода Aristoflex AVC. Проведені технологічні, фізико-хімічні та реологічні дослідження емульсій на основі полімерного регулятора в'язкості аристофрлекс; доведено, що вони є структурованими дисперсними системами з певними тиксотропними властивостями. Результати проведених досліджень свідчать про перспективність використання аристоорлекс в якості моностабілізатора в концентрації 1-2,5\% при вмісті масляної фрази 5-30\% відповідно. Виявлено, що введення Aristoflex у водну або масляну фразу не впливає на їх органолептичні, фрізико-хімічні та реологічні властивості.

\section{ИЗУЧЕНИЕ СВОЙСТВ ПОЛИМЕР-СТАБИЛИЗИРОВАННЫХ ЭМУЛЬСИЙ НА ОСНОВЕ ARISTOFLEX \\ Т.Н.Ковалева, Н.П.Половко \\ Ключевые слова: эмульсия; эмульгатор; полимерные регуляторы вязкости;} реологические свойства; структурная вязкость

Работа содержит исследование стабилизирующих свойств полимерного модификатора вязкости и стабилизатора эмульсионных систем типа масло/вода Aristoflex AVC. Проведены технологические, фризико-химические и реологические исследования эмульсий на основе полимерного регулятора вязкости аристофрлекс; доказано, что они являются структурированными дисперсными системами с определенными тиксотропными свойствами. Результаты проведенных исследований свидетельствуют о перспективности использования аристофрлекса в качестве моностабилизатора в концентрации 1-2,5\% при содержании масляной фразы 5-30\% coответственно. Выявлено, что введение Aristoflex в водную либо масляную фазу не влияет на их органолептические, фризико-химические и реологические свойства. 